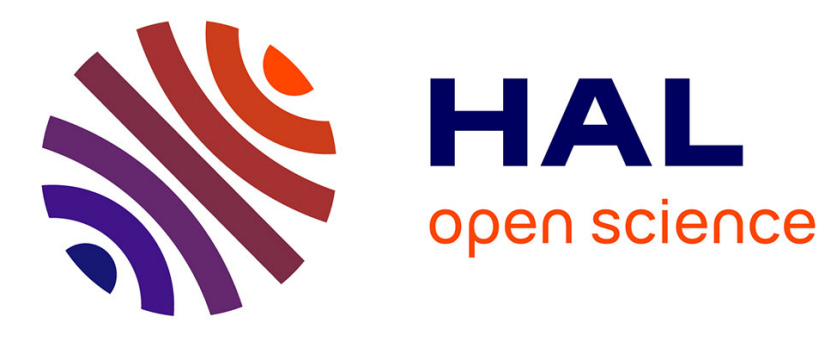

\title{
Lexical scaffolding in immersion classroom discourse
}

\author{
Nathalie Blanc, Rita Carol, Peter Griggs, Roy Lyster
}

\section{To cite this version:}

Nathalie Blanc, Rita Carol, Peter Griggs, Roy Lyster. Lexical scaffolding in immersion classroom discourse. Alcon Soler, E \& Safort-Jorda, M-P. Discourse and language learning across L2 instructional settings, Rodopi B.V. Amsterdam, pp.31-52, 2012, Utrecht Studies in Language and Communication 24. halshs-00801053

\section{HAL Id: halshs-00801053 \\ https://shs.hal.science/halshs-00801053}

Submitted on 15 Mar 2013

HAL is a multi-disciplinary open access archive for the deposit and dissemination of scientific research documents, whether they are published or not. The documents may come from teaching and research institutions in France or abroad, or from public or private research centers.
L'archive ouverte pluridisciplinaire HAL, est destinée au dépôt et à la diffusion de documents scientifiques de niveau recherche, publiés ou non, émanant des établissements d'enseignement et de recherche français ou étrangers, des laboratoires publics ou privés. 


\title{
Lexical scaffolding in immersion classroom discourse
}

\author{
Nathalie Blanc, Rita Carol, Peter Griggs, and Roy Lyster
}

\begin{abstract}
Research in the field of vocabulary learning has shown that child L2 learners need to meet words again and again in new contexts in order to expand and deepen their word knowledge. In an instructional setting, cognitive processing is enhanced not only by the interplay between language use and metalinguistic reflection during classroom interaction but also by the activation and articulation of different sources of knowledge. Building on this research within a socio-cognitive perspective, we conducted quantitative and qualitative analyses of interactional sequences of lexical scaffolding during read-aloud activities in a French immersion primary school in Montreal. In a class composed of a mixture of French dominant, English dominant and bilingual eight-year-olds, French and English versions of the same storybook were read aloud and discussed in alternate lessons by two different teachers. The analyses revealed differences between the two teachers' lexical scaffolding strategies. While the French teacher tended to adopt a metalinguistic focus to elicit the meanings of difficult words, the English teacher sought more to recycle and explore vocabulary in contexts related to the story's content and students' prior experiences and to exploit knowledge of students' first language. These results point to the pedagogical potential of lexical scaffolding that goes beyond word definitions and aims instead to increase learners' depth of processing through connections to cross-lingual, epistemic and experiential knowledge.
\end{abstract}

\section{Introduction}

One of the most widely substantiated outcomes of immersion programs is that students' first language (L1) development and academic achievement are similar to (or better than) those of non-immersion students (Genesee, 1987, 2004; Swain \& Lapkin, 1982; Turnbull, Lapkin, \& Hart, 2001). Another finding common across immersion programs is that students develop much higher levels of second language (L2) proficiency than do non-immersion students studying the $\mathrm{L} 2$ as a subject for about 40 minutes each day. At the same time, research on the L2 proficiency of French immersion students in Canada has long suggested that even higher levels of proficiency approximating native-speaker norms might be attainable through improved instructional strategies (Allen, Swain, Harley, \& Cummins, 1990; Harley, 1993; Harley, Cummins, Swain, \& Allen, 1990; Swain, 1988, 1996). Arguably, the instructional practices designed to foster continued L2 growth through immersion were initially formulated rather tentatively and thus underlie the attested shortcomings that characterize students' L2 proficiency. Immersion pedagogy drew on input-based communicative language teaching theories that emphasized content goals over language goals and avoided explicit attention to language, whereas researchers working across a range of content-based contexts now argue that language learning goals should become more prominent and explicit (e.g., Dalton-Puffer, 2007; Lyster, 2007; Swain \& Lapkin, 2002; Fortune, Tedick \& Walker, 2008;).

In the present study, we explore the instructional discourse of both the French and the English teacher of the same group of French immersion students involved in a biliteracy project. We draw more specifically on the notion of scaffolding (Wood, Bruner, \& Ross, 1976) with a view to identifying effective instructional techniques targeting vocabulary development in the context of teacher-student interaction.

\section{Research background}

\subsection{Instructional strategies}

Lyster (2007) proposed a systematic integration of form-focused and content-based instruction through counterbalanced instruction, which promotes continued language growth by inciting learners to shift their attentional focus in a way that balances their awareness of learning both language and content together. One way for immersion and other content-based teachers to integrate form-focused instruction is through literacy practices that fit within broader educational objectives. This is because at the core of early literacy instruction is the need to nurture learners' awareness of oral language and their ability to conceptualize language: "becoming aware of it as a separate structure, freeing it from its embeddedness in events" (Donaldson, 1978, p. 90).

Previous research into literacy instruction in immersion settings has revealed an overall lack of planned vocabulary instruction as well as an overemphasis on decoding and understanding difficult words during reading activities (e.g., Allen, Swain, Harley, \& Cummins, 1990). Stemming from this research are recommendations for more explicit vocabulary instruction within communicative contexts that include cross-lingual teaching strategies and reference to cognates to alert students to differences and also similarities between their L1 and L2 (Allen et al., 1990; Clipperton, 1994; Cummins, 2007). Other studies advocate focusing students' attention on 
the interplay between language knowledge and epistemic knowledge in immersion settings as a way of enriching lexical processing (Carol, 2008; Serra \& Steffen, 2010).

In line with these recommendations, research into vocabulary development through reading points to an important role for 'depth of processing' in vocabulary instruction (Hulstijn, 2003; Laufer, 2003, 2006). Cameron (2001) summed up the importance of depth of lexical processing even for young learners as follows:

Vocabulary development is not just learning more words but is also importantly about expanding and deepening word knowledge. Children need to meet words again and again, in new contexts that help increase what they know about words. Teaching needs to include the recycling of words. (p. 81)

To facilitate the recycling of words in this way, teachers are encouraged to focus on frequent and useful words while adopting an explicit approach to help learners, especially at the beginning stages, to make connections between form and meaning (Schmitt, 2008). Cameron (2001) stresses that, with young learners, exposure to new words in this way needs to occur not only in isolation but also in meaningful discourse contexts.

\subsection{A socio-cognitive view of learning}

Content-based instructional approaches to second language learning and teaching generally draw support from a range of theoretical perspectives. As Echevarria and Graves (1998) stated in reference to sheltered content classrooms, "effective teachers typically use a balanced approach that includes choices rooted in different learning theories" (p. 36). The theoretical perspective adopted in our study attributes complementary roles to both cognition and social interaction in L2 learning, and thus draws on a socio-cognitive perspective, which brings together Anderson's work on skill acquisition (Anderson 1982) and Bruner's work on scaffolded interaction (see Bange, Carol, \& Griggs, 2005; Griggs 2007). Incorporating Bruner's (1971) argument that "growth of mind is always growth assisted from the outside" (p. 52), a socio-cognitive view of learning applies aptly to school settings, where "learning is a social as well as a cognitive process, one influenced by the relationships between student and teacher and among students" (August \& Hakuta, 1997, p. 85).

With respect to skill acquisition, Bange et al. (2005) argued that, in second or foreign language teaching, there has been a tendency for instruction to be considered sufficient even if it aims only to develop declarative knowledge, without proceeding to the next step of providing opportunities for students to proceduralize their declarative knowledge. They also identified an obvious challenge in this regard: the development of procedural knowledge entails "learning by doing" (see Bruner, 1971), so learners are expected, paradoxically, to participate in tasks which they are not yet able to accomplish autonomously. They argued that the solution to the paradox lies in social interaction and, more specifically, in Bruner's notion of scaffolding between expert and novice, which "enables a child or novice to solve a problem, carry out a task or achieve a goal which would be beyond his unassisted efforts" (Wood, Bruner, \& Ross, 1976, p. 90). Taking on the mentoring role, teachers promote the appropriation of new knowledge as they provide the amount of assistance that students need until they are able to function independently.

\section{The Present Study}

The study we report on in this chapter was conducted in a grade 3 French immersion classroom in the province of Quebec, where Canadian French immersion programs were first launched with homogenous groups of English-speaking children in 1965 (Lambert \& Tucker, 1972). Classrooms in this context are, however, increasingly heterogeneous, now consisting of a mixture of French-dominant, English-dominant, and French/English bilingual students (Lyster, Collins, \& Ballinger, 2009).

In this study, we examine the ways in which the French and English teachers of the same group of French immersion students draw attention to vocabulary during a bilingual read-aloud project. Vocabulary-focused episodes were selected from 4 hours of teacher-student interaction relating to a chapter book about ancient China that was read aloud to a grade 3 class of 24 8-9-year-old children. This particular dataset comes from a transcribed corpus of 27 hours of interactional data collected by Lyster, Collins, and Ballinger (2009) in the context of their bilingual read-aloud project in which French and English teachers read aloud to their students from the same storybooks alternating between chapters in French and English. Their study involved six teachers and their 68 students, with one pair of English and French teachers teaching a grade 1/2 class, a second pair teaching a grade 2 class, and a third pair teaching grade 3 . Their data consisted of video-recordings of the readaloud sessions and discussion about the stories. The transcribed corpus is rich in interactional data because, before each read-aloud session, teachers asked their students to summarize the content of the previous chapter 
(read in the 'other' language), and, after each reading, they asked students to make predictions about the next chapter. The goals of their study were (a) to raise teachers' awareness of the bilingual resources of their students, (b) to encourage students' cross-linguistic collaboration, and (c) to promote teachers' cross-curricular and crosslinguistic collaboration.

In the present study, we zero in on the two grade 3 teachers because it was this grade level that proved most suitable to the selected storybooks, all of which were written by Mary Pope Osborne, published in English in the Magic Tree House series by Random House and in French in the Cabane Magique series by Bayard Jeunesse. The theme across all three stories was "books" and how writing changes across time and space. The main characters in each story were the same two children who were given a mission in each story to travel back in time in a magic tree house to recover books in danger of being lost or destroyed. In the present study, we chose to examine interaction during the reading of the second of three books, which was Day of the Dragon King (Osborne, 1998) in English and Le terrible empereur de Chine (Osborne, 2003) in French. In this story, the duo is sent to ancient China to retrieve the Chinese legend of the silk weaver and the cowherd. Readers become aware that, in ancient China, before the invention of paper, books were made of bamboo strips displaying Chinese calligraphy.

The grade 3 class consisted of 24 students: 8 English-dominant, 8 French-dominant, and 8 French/English bilinguals. The French teacher was a francophone with minimal knowledge of English. She had taught at the school for 7 years. She had a Bachelor of Education degree from a French-speaking university, with a focus on special-needs students, but no specific teacher training in L2 teaching. The English teacher was bilingual in English and Greek and had some knowledge of French. She had completed a one-year teaching program prior to becoming an elementary school teacher and, like her counterpart, had no specific training in L2 teaching. She had taught grades 3 and 4 at the school for 22 years and had begun teaching English language arts in the French immersion stream 10 years earlier.

Both teachers focused a great deal on vocabulary during their reading of the story as well as before and after while students were retelling the previous chapter and making predictions for the next. However, the teachers appeared to use very different strategies to focus on vocabulary; hence the idea of a descriptive study of two different teachers working with the same group of students on related content (i.e., the same story) but in two different languages.

Our goal in this chapter is, first, to identify these strategies and the extent to which they engage students, and second, to speculate about their potential effectiveness in the light of the recommendations highlighted in our literature review whereby child L2 learners need to meet words again and again in new contexts, ideally in communicative contexts, in order to expand and deepen their word knowledge. We examine classroom discourse as two teachers take on a mentoring role to facilitate the appropriation of new vocabulary by scaffolding the interaction in ways that promote varying degrees of lexical processing.

\section{Method of coding}

Our coding categories are data driven, deriving from repeated viewings of the videos and careful readings of the transcripts. Our analysis of the two sets of classroom data led us first of all to identify what we refer to as lexical scaffolding episodes. These are characterised by the signalling and decontextualisation of lexical forms or meanings during a read-aloud or summary phase of the lesson, followed by an interactional sequence which involves the class in a lexical search giving rise to the emergence of the targeted lexical form or meaning.

The dominant underlying interactional pattern which emerged from our analysis of both teachers was the discourse sequence Initiation-Response-Feedback identified by Sinclair and Coulthard (1975). This determined the way in which we apprehended the structure of each lexical episode, the lexical search generally presenting itself in the form of a sequence initiated by the teacher. In most cases, the initiation takes the form of a question which triggers the lexical search. In example 1, the teacher's question focuses on a difficult word in the text and asks for a definition :

Example 1

FT je vais te demander des mots difficiles, je veux savoir si tu comprends bien «Il dévale les escaliers » Mmm... dévaler, le verbe... » (FT-3).

In example 2, the lexical search is set off during a student turn in which the appropriate word in English is missing : 
Example 2

S they went... they went in their [cabane].

ET: they went in their [cabane]. What's another word for [cabane]? (ET-1).

We identified four types of orientation underlying the instructional interaction during these episodes, determined either by the teacher's scaffolding strategies or by the students' output (responses or autonomous turns).

A (meta)linguistic orientation involves a search for a lexical form or a word definition, calling on language knowledge which may also include reflection on language. This orientation naturally underlies all the lexical scaffolding episodes and systematically constitutes the opening orientation in so far as the episodes are initiated by the decontextualisation of language knowledge (see example 1).

A cross-lingual orientation entails reference to the knowledge of the "other" language and can either be triggered by the teacher or emerge in the students' production (see example 2).

An epistemic orientation relates either to general world knowledge or to the content of the story being read, as in the following example:

Example 3

ET [Ancien.] Did you hear that word [ancien] or ancient country in the previous book that we read? (ET-1).

An experiential orientation draws on knowledge based on students' personal experience. In the following example, the teacher has recourse to objects and activities linked to the personal lives of the students in order to clarify the meaning of the lexical item "thread":

Example 4

ET Cotton threads, so it's cord any kind of cord that we weave into cloth. How many of you have tents at home? Tents? How many of you go camping or have a little tent in your backyard? (ET-17$10)$.

As language necessarily articulates form and meaning, the boundaries between linguistic and non-linguistic orientations are often difficult to define. Our coding decisions are therefore not always unequivocal but based on our judgment of the degree to which a word is, on the one hand, the object of metalinguistic focus and, on the other hand, embedded in a communicative activity.

Finally, a distinction was made between student responses and autonomous student turns according to whether the student output is linked or not to a previous teacher initiating turn in the elicitation sequence.

\section{Quantitative analysis}

The aim of this quantitative analysis was, first of all, to classify and quantify different orientation patterns, secondly, to measure their effect on the amount of student output and, finally, to explore the effects of orientation changes on lexical processing.

\subsection{Classification and quantification of orientation patterns}

The first elements which appear in our quantitative analysis are that $32 \%$ of the French teacher's (FT) episodes display a single orientation which is exclusively linguistic or metalinguistic, whereas in the English teacher's (ET) class the percentage of single-oriented episodes is less than half as much (12\%) (Table 1). Furthermore, $61 \%$ of FT's episodes have a double orientation and only two episodes out of $28(7 \%)$ show a triple orientation. On the other hand, ET's episodes present a much richer configuration of patterns, with a significantly higher rate of episodes combining three orientations (24\%) and 5\% of episodes combining all four.

\begin{tabular}{lcc}
\hline & FT & ET \\
\hline Single orientation ((meta)linguistic) & 9 & 5 \\
& $(32 \%)$ & $(12 \%)$ \\
Double orientation & 17 & 24 \\
& $(61 \%)$ & $(59 \%)$ \\
Triple orientation & 2 & 10 \\
& $(7 \%)$ & $(24 \%)$ \\
Quadruple orientation & 0 & 2 \\
\hline
\end{tabular}




\begin{tabular}{lcc}
\hline & & $(5 \%)$ \\
total & 28 & 41 \\
\hline
\end{tabular}

\section{Table 1:}

Number (and percentage) of sequences per teacher with single, double, triple or quadruple orientations

The sequences in the multiple-oriented episodes show, for both teachers, a preference for scaffolding patterns combining a (meta)linguistic and an epistemic orientation. In the double orientation category, this is the case for $46 \%$ of FT's episodes and for 34\% of ET's episodes (Table 2) and this combination is also the most recurrent in triple-oriented episodes with $7 \%$ for FT and $22 \%$ for ET (Table 3 ). The predominance of this scaffolding pattern can be explained by the fact that the lexical processing takes place in the context of a content-oriented pedagogical activity. The most substantial distinguishing feature between the two teachers is that, in comparison to FT's lexical scaffolding episodes, those of ET incorporated a higher proportion of experiential references $(19 \%$ vs. $10 \%)$ and an even greater proportion of cross-lingual references ( $42 \% \mathrm{vs} .11 \%)$ as a means to explore and consolidate the meaning of words (Tables 2, 3, \& 4).

\begin{tabular}{lcc}
\hline & FT & ET \\
\hline (meta)linguistic + cross-lingual & 3 & 8 \\
& $(11 \%)$ & $(20 \%)$ \\
(meta)linguistic + epistemic & 13 & 14 \\
& $(46 \%)$ & $(34 \%)$ \\
(meta)linguistic + experiential & 1 & 2 \\
& $(3 \%)$ & $(5 \%)$ \\
\hline total & 18 & 24 \\
& $(64 \%)$ & $(59 \%)$ \\
\hline
\end{tabular}

\section{Table 2}

Number (and percentage) of sequences per teacher with different double-orientation combinations

\begin{tabular}{|c|c|c|}
\hline & FT & ET \\
\hline (meta)linguistic + cross-lingual + epistemic & 0 & $\begin{array}{c}6 \\
(15 \%)\end{array}$ \\
\hline (meta)linguistic- + cross-lingual + experiential & 0 & $\begin{array}{c}1 \\
(2 \%)\end{array}$ \\
\hline (meta)linguistic + epistemic + experiential & $\begin{array}{c}2 \\
(7 \%)\end{array}$ & $\begin{array}{c}3 \\
(7 \%) \\
\end{array}$ \\
\hline total & $\begin{array}{c}1 \\
(7 \%)\end{array}$ & $\begin{array}{c}10 \\
(24 \%)\end{array}$ \\
\hline
\end{tabular}

Table 3

Number (and percentage) of sequences per teacher with different triple-orientation combinations

\begin{tabular}{ccc}
\hline & FT & ET \\
\hline (meta)linguistic + cross-lingual + epistemic + experiential & 0 & 2 \\
& $(5 \%)$ \\
\hline
\end{tabular}

Table 4

Number (and percentage) of sequences per teacher with a quadruple orientation

\subsection{Effects of orientation patterns on the amount of student output}

Our first hypothesis deriving from the notion of depth of processing presented in the literature review and from the results of the preceding quantitative study was that lexical scaffolding engaging students communicatively should benefit lexical processing in that it fosters the recycling of words in a meaningful discourse context. Working on this hypothesis, we sought to relate the categories of scaffolding orientation to the amount of student output generated during the interactional sequence. The effect of lexical scaffolding on the quantity of student output was measured in terms of the number and the length of student turns. For both teachers, we counted the average amount per episode of student turns and the average amount per episode of student turns containing one sentence or more. 
Table 5 shows that the average amount of student turns per episode increases in proportion to the number of orientations within the episode: an average of 2.7 turns for single-oriented episodes, 4 turns for double-oriented episodes, 10.2 turns for triple- and quadruple-oriented episodes. A similar rate of increase can be observed for the number of student turns containing one sentence or more: an average of 0.9 for single-oriented episodes, 1.7 for double-oriented episodes, 4.5 for triple- and quadruple-oriented episodes. Table 5 also shows that these rates are similar for both FT and ET and do not appear therefore to be affected by the teacher variable.

\begin{tabular}{llccc}
\hline orientations & number of \\
episodes & $\begin{array}{c}\text { average student } \\
\text { turns }\end{array}$ & $\begin{array}{c}\text { average student } \\
\text { turns of one } \\
\text { sentence or } \\
\text { more }\end{array}$ \\
\hline single ((meta)linguistic) & FT & 9 & 2.8 & 1.2 \\
& ET & 4 & 2.5 & 0.2 \\
\hline double & FT + ET & 13 & 2.7 & 0.9 \\
\hline triple \& quadruple & FT & 17 & 4.4 & 2.4 \\
& ET & 25 & 3.7 & 1.1 \\
& FT + ET & 42 & 4.0 & 5.0 \\
\hline
\end{tabular}

Table 5:

Volume of output related to orientation patterns

Table 6 relates student output to combinations of lexical orientations within multiple-oriented episodes. A distinction is made between episodes involving combinations where the linguistic orientation (i.e., (meta)linguistic and/or cross-lingual) is dominant and those where the non-linguistic orientation (i.e., epistemic and/or experiential) is dominant. Average student output is shown to be higher in episodes where non-linguistic orientations exceed linguistic ones. In double-oriented episodes, combinations of linguistic and non-linguistic orientations generate an average of 4.2 student turns compared to 3.5 in exclusively linguistic ((meta)linguistic/cross-lingual) combinations and an average of 1.9 student turns of one sentence or more in the former compared to an average of 1 in the latter. In triple- and quadruple-oriented episodes, the gap between non-linguistically and linguistically dominant orientations is even greater: an average of 12.5 compared to an average of 3.5 for the rate of student turns and an average of 6 compared to an average of 1.2 for the rate of student turns of one sentence or more.

\begin{tabular}{clccc}
\hline $\begin{array}{c}\text { number of } \\
\text { orientations }\end{array}$ & combination of orientations & $\begin{array}{c}\text { number of } \\
\text { episodes }\end{array}$ & $\begin{array}{c}\text { average student } \\
\text { turns }\end{array}$ & $\begin{array}{c}\text { average student } \\
\text { turns of one } \\
\text { sentence or } \\
\text { more }\end{array}$ \\
\hline double & (meta)linguistic/crosslingual & 11 & 3.5 & 1.0 \\
& linguistic/non-linguistic & 31 & 4.2 & 1.9 \\
\hline triple \& & linguistic dominant & 12 & 3.5 & 1.2 \\
quadruple & non-linguistic dominant & 5 & 12.5 & 6.0 \\
\hline
\end{tabular}

Table 6:

Volume of output in linguistically dominant and non-linguistically dominant orientation episodes

The results of this quantitative analysis show therefore that student output increases in proportion to the diversity of orientations underlying the teachers' lexical scaffolding strategies and to the degree to which these orientations are non-linguistic. According to our first hypothesis, such instructional strategies should be beneficial to lexical processing in that they engage students communicatively and thereby allow words to be recycled.

\subsection{Effects of orientation changes on lexical processing}

Our second hypothesis was that lexical processing is enhanced in this instructional setting by the interplay during classroom interaction between different sources of knowledge. In the light of this hypothesis, we decided to count the number of changes, whatever type of orientation they involve, which take place during the multipleoriented episodes. This led us also to examine more precisely who initiates these changes, the teacher or the 
students.

We counted as changes switches in orientation initiated both by the teacher after feedback and by students in their responses or autonomous turns. Thirty-seven orientation changes were found in the 28 episodes scaffolded by FT, giving an average rate of 1.3 changes per episode, whereas for ET the rate is much higher, amounting to 97 changes of orientation in 41 episodes, with an average of 2.4 per episode. On the other hand, the relative proportions are inverted in the two teaching contexts regarding the number of changes initiated by the students or by the teacher: $43 \%$ of these changes are initiated by the students in FT's case, whereas for ET, the rate is lower at $29 \%$. These figures show, therefore, that in FT's class, the pupils take more responsibility for changes in orientation than in ET's class.

As for the number of autonomous turns taken by the students, an opposite tendency can be observed. Indeed, 11 student autonomous turns were counted in FT's episodes, giving an average of 0.4 per episode, while in ET's class, this figure is more than doubled: 35 autonomous turns were found with an average of 0.8 per episode. The relative proportion of different types of orientation within the autonomous student turns also varies according to the teacher. In the case of FT, $63.6 \%$ of these student turns are (meta)linguistically oriented, $27.3 \%$ have an epistemic orientation and $9.1 \%$ an experiential orientation. In ET's case, the relative proportion is different and more balanced and also includes cross-lingual oriented turns. The highest rate $(40 \%)$ is that of epistemic orientation, with (meta)linguistic orientation at $31.4 \%$, experiential at $22.8 \%$ and cross-lingual at $5.8 \%$.

These results imply that in ET's class the students' output is both more content-based and more spontaneous, seeming in the second case to contradict the previous results showing that it is in FT's class that the students take more responsibility for orientation changes. The lower rate of student-initiated orientation changes in ET's class could be explained by the fact that she herself switches orientation a lot more than FT. The rate of switches is lower in FT's case, but the percentage of changes initiated by the students is higher. We speculate therefore that the students themselves feel the need to switch orientation in order to process vocabulary and that this need is not addressed sufficiently by FT's scaffolding strategies based primarily on a (meta)linguistic orientation.

In the light of the research presented in the literature review, the results of the quantitative analysis lead us to formulate two further hypotheses regarding the effect on lexical processing of these changes in orientation :

- Hypothesis 1: A switch from a linguistic to a non-linguistic orientation during a scaffolding episode may both facilitate lexical access by clarifying meaning through a process of contextualisation and increase the depth of lexical processing by recycling vocabulary in communicative discourse.

- Hypothesis 2: A switch from a non-linguistic to a (meta)linguistic or cross-lingual orientation may allow the learners to consolidate meaning and deepen lexical processing by articulating different types of language knowledge.

\section{Qualitative analysis}

In order to explore these two hypotheses we carried out a qualitative analysis of two lexical scaffolding episodes representative of the strategies displayed by the two teachers and both involving multiple orientations: the episode «paisible» taken from FT's class and the episode «pasture » taken from ET's class. This qualitative analysis draws on socio-cognitive theory by relating the scaffolding strategies used by the two teachers to the type of pedagogical relationship that emerges during the interaction.

The "paisible" episode is triggered when FT draws the students' attention to a difficult word (paisible = peaceful) in order to check comprehension during the read-aloud activity.

"Paisible" Episode: Extract 1

\begin{tabular}{|l|l|}
\hline 1FT & $\begin{array}{l}\text { Alors, je commence? « Un pays si paisible » Qu'est-ce que ça veut dire le mot paisible? un pays paisible, } \\
\text { mmm... quelqu'un là qui parle beaucoup anglais à la maison, serait capable de me dire ça? xxx, tu parles } \\
\text { anglais beaucoup à la maison - comment? }\end{array}$ \\
\hline 2S & Comme c'est l'eau... \\
\hline 3FT & $\begin{array}{l}\text { Un pays pais--. xxx! pense au mot paisible, tu lèves la main. C’est beau? xxx baisse la main tout de suite, } \\
\text { assis-toi sur tes fesses, xxx! Alors, un pays... pense à la Chine... un pays paisible, j'aimerais ça là, } \\
\text { quelqu'un qui par--... xxx, tu parles beaucoup anglais à la maison dis-le donc }\end{array}$ \\
\hline 4Sd & euh... c'est un pays... beau... \\
\hline 5FT & $\begin{array}{l}\text { Beau? Non Pense à un autre petit mot dans le grand mot. Vas-y donc ...ah...xxx! dernier avertissement. } \\
\text { Paisible ? xxx; }\end{array}$ \\
\hline 6 & euh.. admettons un exemple ....eh...quelqu'un qui pèse beaucoup ? (laughter) \\
Sd
\end{tabular}




\begin{tabular}{|l|l|}
\hline 7FT & Qui pèse beaucoup ? Non.. \\
\hline 8 & Je sais, je sais! \\
Sd & \\
\hline 9FT & Pour moi c'est un mot facile, mais je crois que c'est difficile. Oh la la! xxx? \\
\hline
\end{tabular}

In Extract 1, three attempts by FT to elicit the meaning of "paisible" lead to student responses which all receive negative feedback from the teacher. An initial linguistically oriented elicitation "qu'est-ce que ça veut dire le mot paisible?" gives rise to the student response "comme c'est l'eau" which attempts to define the word by associating it to an analogous context, that of water. In so doing the student departs from a purely linguistic orientation to evoke a context more embedded in personal experience. In contrast, the third elicitation, strongly focusing on lexical form - "pense à un autre petit mot dans le grand mot" - imposes a strict metalinguistic framework which induces a student to produce a wrong answer: "quelqu'un qui pèse beaucoup", which nevertheless shows evidence of a clever metalinguistic deduction. Between these two (meta-)linguistically oriented elicitations, FT changes to an epistemic orientation in order to facilitate the lexical search through the evocation of China, the country in which the story is set : "alors un pays... pense à la Chine... un pays paisible." However, this change in orientation also leads to an inadequate reply ("c'est un pays... beau"), as the feature targeted by the teacher in the very general context she evokes is not sufficiently evident to be mutually recognized by the group.

We consider that the failure of FT's elicitations to achieve the expected outcomes in this extract can be linked to the type of pedagogical relationship she establishes with the class. By choosing to explore language in a predominantly metalinguistic framework, which she herself and the French-dominant students master better than the English-dominant students, she induces a more asymmetrical relationship in which knowledge is exchanged on an unequal basis and constructed according to the expectations of the teacher. The task of lexical processing is thus made all the more difficult especially for English-dominant students. This asymmetry is reinforced by her insistence on specifically designating English-dominant students to respond to her elicitations (turns 1 and 3 ) and by her deliberate choice, repeated in other sequences, of drawing students' attention to difficult words. When her scaffolding strategy does take on a non-linguistic epistemic orientation, the features she tries to bring to the students' minds through the context she evokes are not sufficiently manifest to support lexical processing.

In contrast, FT achieves her objective at the end of the same sequence, in Extract 2, by presenting the word in a shared framework constructed on the basis of the students' personal experience - "quand tu as la paix, disons à la maison? Tu es comment? Tu te retrouves, c'est...?" - thus allowing students to rapidly find appropriate synonyms "tranquille" and "calme".

"Paisible" Episode: Extract 2

\begin{tabular}{|l|l|}
\hline 17FT & Ok! sh...quand tu as la paix, disons à la maison? Tu es comment? Tu te retrouves, c'est...? \\
\hline 18Ss & Tranquille \\
\hline 19FT & $\begin{array}{l}\text { Tranquille! Alors, qu'est-ce que ça veut dire un pays pai-sible. Sh....non, je vais aller voir (?) qui a la main } \\
\text { levée }\end{array}$ \\
\hline 20Sd & euh... calme? \\
\hline 21FT & Bon! un pays calme. Ça va? On y va! \\
\hline
\end{tabular}

The "pasture" episode, taken from the corpus of the English class, takes place during a summary phase in which the teacher isolates the word "pasture" as part of a comprehension check of the chapter which has just been read aloud. The analysis of the extracts shows how the scaffolding sequence triggered by this word leads the students to explore the word's semantic field by switching to and fro between linguistic and non-linguistic orientations.

After ET's linguistically oriented initiating turn fails to elicit an adequate response in Extract 3, she switches immediately to an epistemic orientation in which she reconstitutes contextual features taken from the story so as to help the students infer the targeted meaning. By recycling the students' previous output she reinforces the mutually recognized context: "on a farm where someone said like a garden where you have a field, animals go to the to pasture (...) you have in the countryside most of you said it." When this strategy also fails to lead the students to an adequate response, ET carries on in the same orientation by showing a picture from the book. This picture serves as a semiotic tool enabling knowledge to be shared.

"Pasture" Episode: Extract 3

1ET No? Ok. Did everyone understand the word pasture? Raise your hand if you know what pasture is. There was 


\begin{tabular}{|l|l|}
\hline & the word pasture. What's a pasture? (points to one student) \\
\hline 2S & It's- ok, I don't remember \\
\hline 3ET & $\begin{array}{l}\text { On a farm where someone said like a garden where you have a field, animals go to the to pasture. } \\
\text { What does that mean? Animals go animals go to pasture. You have in the countryside most of you said } \\
\text { it. There were gardens next to the garden is usually a pasture. xxx what's a pasture? }\end{array}$ \\
\hline 4S & I think it's like in a barn or something \\
\hline 5ET & No it isn't, it's not a building. \\
\hline 6Sd & On a farm. \\
\hline 7ET & It's on look... look behind and you can see the pasture (shows picture in book). \\
\hline
\end{tabular}

Later on in the sequence in Extract 4, ET switches, with the same objective of building shared knowledge, to an experiential orientation. This generates a large amount of student output based upon personal experience, leading them to recycle words of the same semantic field (farm, acres, field, yard) in a meaningful context. Furthermore, the teacher's authentic questioning ("how many of you have ever gone on a farm?", "ok so when you look out the window from your papa's house what do you see outside?") induces a symmetrical relationship by inverting the typical pedagogical interaction with regard to the source of knowledge.

"Pasture" Episode: Extract 4

\begin{tabular}{|l|l|}
\hline 15ET & $\begin{array}{l}\text { If we, how many of you have ever gone on a farm? (Some hands go up) Ok xxx you've gone on a } \\
\text { farm? }\end{array}$ \\
\hline $16 \mathrm{Sd}$ & So it's kind of a farm it's where my papa lives he lives in this big big area. \\
\hline 15ET & Ok so when you look out the window from your papa's house what do you see outside? \\
\hline $16 \mathrm{Sm}$ & Well usually I see like yards with acres and acres of yard and stuff like that. \\
\hline 17ET & Acres and acres of what? \\
\hline 18Sm & Yard. \\
\hline 19ET & Yard? Do you mean what, a field? \\
\hline 20Sm & Yeah. \\
\hline 21ET & A field. \\
\hline
\end{tabular}

At the end of this sequence in Extract 5 the class first returns to a linguistic orientation and then finally switches to a cross-lingual one. Within the experiential context collectively constructed by the class, the teacher's question - "What are they standing on?" - takes on a lexical orientation by directly pointing to words that are linked to the targeted meaning. This question enables the class to constitute through their interaction a network of associated words ("grass", "field", "land", "trees"). By evoking a shared experience - "so you've all walked across a pasture" - the teacher then goes on to establish these words as belonging to the same lexical field as "pasture".

Finally, in order to consolidate further the meaning of the word, the teacher asks French-dominant students to provide a translation in French. A more symmetrical relationship is thus once more induced by an inversion in the normal flow of knowledge: French-dominant students are designated in their capacity as "experts" in their native language while the teacher herself masters only partially what for her is a foreign language.

"Pasture" Episode: Extract 5
\begin{tabular}{|l|l|}
\hline 29ET & You just saw animals. Where were they standing? What were they standing on? \\
\hline $30 \mathrm{Sm}$ & They were standing on the ... \\
\hline $31 \mathrm{Sd}$ & Grass? \\
\hline $32 \mathrm{~S}$ & Yeah \\
\hline 33ET & Grass. So another word for grass in the countryside is pasture. How many? \\
\hline $34 \mathrm{~S}$ & Fields? \\
\hline 35ET & Fields yes fields of grass is a pasture. \\
\hline $36 \mathrm{Sd}$ & Land. \\
\hline 37ET & $\begin{array}{l}\text { Land, trees. F1 How many of you like to run in the fields in the countryside? (most students raise their } \\
\text { hands) So you've all walked across a pasture. }\end{array}$ \\
\hline $38 \mathrm{~S}$ & Ah, Miss xxx? \\
\hline 39ET & So, how would we say pasture in French? Who would like to take a chance? xxx? \\
\hline \multicolumn{2}{|l|}{} \\
\hline 47ET & $\begin{array}{l}\text { So what does that mean, [pasture]? xxx I'm concerned now that you're talking because you're not } \\
\text { listening. }\end{array}$ \\
\hline 48S & [Pasture] means- \\
\hline
\end{tabular}




\begin{tabular}{|l|l|}
\hline 49ET & So [pasture], xxx do you know what [pasture] means in English or in French? \\
\hline $50 \mathrm{~S}$ & [Un champs] \\
\hline 51ET & [C'est un champs] a field exactly. \\
\hline
\end{tabular}

In summary, therefore, the main difference between the instructional strategies of FT and ET is that the latter are characterized by a more communicative and symmetrical mode of pedagogical interaction in which information is exchanged more horizontally and knowledge constructed more collectively in shared contexts. We hypothesize that this mode of pedagogical interaction, involving the exploration of vocabulary in different discourse contexts, is more likely to develop procedural lexical skills by encouraging the recycling of words in meaningful contexts and to foster depth of processing through the interplay between different sources of lexical knowledge.

\section{Conclusion}

Starting from the premise that effective teaching in immersion contexts requires appropriate instructional techniques designed specifically to promote language development, this study has analysed lexical scaffolding strategies used by teachers and their potential effect on the type of lexical processing carried out by students. In view of the descriptive nature of its research design, the aim of the study was not to measure the effects on vocabulary learning of different types of lexical scaffolding strategy, but rather to explore the correlations between teachers' scaffolding strategies, students' cognitive focusing and the pedagogical relationships established during instructional interaction. Our quantitative analysis of the lexical scaffolding episodes managed by the two teachers participating in this study revealed differences in the strategies they use. While the French teacher favoured a metalinguistic focus to elicit definitions of difficult words from students, the English teacher tended to recycle and explore vocabulary in different contexts, thus allowing words to be processed in relation to epistemic content, students' prior experiences, and students' first language. In the light of the research literature, the quantitative analysis suggested that the scaffolding patterns in the English class provide particularly favorable interactional conditions for the recycling of words and for depth of processing. The qualitative analysis, drawing on a socio-cognitive perspective, then allowed us to explore more deeply these interactional conditions and to show how they correlate positively with the type of pedagogical relationship the teacher establishes with her students.

Creating purposeful opportunities in meaningful contexts for recycling words in ways that promote depth of lexical processing is advocated as an effective means to stimulate vocabulary development. Yet, how teachers can effectively employ such strategies during online interaction with students is less well documented and requires concrete examples that might serve as models for professional development. Noteworthy in this regard in our analysis is how one teacher in particular was able to recycle words within a single lesson by shifting students' attention from metalinguistic and crosslinguistic orientations to epistemic and experiential orientations. She maintained a recursive interplay between these orientations, thereby counterbalancing a focus on language and content in ways that required shifts in students' attention and thus deeper levels of lexical processing. We expect to continue this line of research by investigating in more detail the discourse features that enable teachers to orchestrate their lexical scaffolding in this way.

\section{References}

Allen, P., Swain, M., Harley, B., \& Cummins J. (1990) Aspects of classroom treatment: Toward a more comprehensive view of second language education. In B. Harley, P. Allen, J. Cummins, \& M. Swain (Eds), The development of second language proficiency, Cambridge, UK: Cambridge University Press: 57-81. Anderson, J. (1982). Acquisition of Cognitive Skill. Psychological Review, 89 (4), 396-406.

August, D., \& Hakuta, K. (Eds) (1997) Improving schooling for language-minority children: A research agenda. Washington, DC: National Academy Press.

Bange, P. (with Carol, R., \& Griggs, P.) (2005) L'apprentissage d'une langue étrangère : cognition et interaction, Paris: L’Harmattan.

Bruner, J. (1971) The relevance of education, New York: Norton.

Cameron, L. (2001) Teaching languages to young learners, Cambridge, UK: Cambridge University Press.

Carol, R. (2008) Langue et cognition : apprendre les concepts de couleur et de taille en classe d'immersion à l'école primaire. Etudes de Linguistique Appliquée 151: 319-331.

Clipperton, R. (1994) Explicit vocabulary instruction in French immersion, The Canadian Modern Language Review, 50: 737-749. 
Dalton-Puffer, C. (2007) Discourse in content and language learning (CLIL) classrooms, Amsterdam: John Benjamins.

Donaldson, M. (1978) Children's minds, New York: Norton.

Echevarria, J., \& Graves, A. (1998) Sheltered content instruction, Boston: Allyn \& Bacon.

Fortune, T., Tedick, D., \& Walker, C. (2008) Integrated language and content teaching: Insights from the immersion classroom. In T. Fortune and D. Tedick (Eds), Pathways to multilingualism: Evolving perspectives on immersion education, Clevedon, UK: Multilingual Matters.

Genesee, F. (1987) Learning through two languages: Studies of immersion and bilingual children, Cambridge, MA: Newbury House.

Genesee, F. (2004) What do we know about bilingual education for majority language students? In T. K. Bhatia \& W. Ritchie (Eds), Handbook of bilingualism and multiculturalism, Malden, MA: Blackwell: 547-576.

Griggs, P. (2007) Perspective sociocognitive sur l'apprentissage des langues étrangères, Paris: L'Harmattan.

Harley, B. (1993) Instructional strategies and SLA in early French immersion, Studies in Second Language Acquisition, 15: 245-259.

Harley, B., Cummins, J., Swain, M., \& Allen, P. (1990) The nature of language proficiency. In B. Harley, P. Allen, J. Cummins \& M. Swain (Eds), The development of second language proficiency, Cambridge, UK: Cambridge University Press: 7-25.

Hulstijn, J. (2003) Incidental and intentional learning. In C. Doughty \& M. Long (Eds), Handbook of second language acquisition, Oxford: Blackwell: 349-381.

Lambert, W., \& Tucker, R. (1972) Bilingual education of children: The St. Lambert experiment, Rowley, MA: Newbury House.

Laufer, B. (2003) Vocabulary acquisition in a second language: Do learners really acquire most vocabulary by reading? Some empirical evidence, The Canadian Modern Language Review, 59: 567-588.

Laufer, B. (2006) Comparing focus on form and focus on forms in second language vocabulary learning, The Canadian Modern Language Review, 63: 149-166.

Lyster, R. (2007) Learning and teaching languages through content, Amsterdam: John Benjamins.

Lyster, R., Collins, L., \& Ballinger, S. (2009) Linking languages through a bilingual read-aloud project, Language Awareness, 18: 366-383.

Osborne, M. (1998) Day of the Dragon King, New York: Random House.

Osborne, M. (2003) Le terrible empereur de Chine, Paris: Bayard Jeunesse.

Schmitt, N. (2008) Review article: Instructed second language vocabulary learning, Language Teaching Research, 12: 329-363.

Serra, C. \& Steffen, G. (2010) Acquisition des concepts et intégration des langues et disciplines dans l'enseignement bilingue. In Carol, R. (Eds) Apprendre en classe d'immersion. Quels concepts? Quelle théorie?, Paris: L'Harmattan: 129-186.

Sinclair, J., \& Coulthard, R. M. (1975) Towards an analysis of discourse: The English used by teachers and pupils, Oxford: Oxford University Press.

Swain, M. (1988) Manipulating and complementing content teaching to maximize second language learning. TESL Canada Journal, 6: 68-83.

Swain, M. (1996) Integrating language and content in immersion classrooms: Research perspectives, The Canadian Modern Language Review, 52: 529-548.

Swain, M., \& Lapkin, S. (1982) Evaluating bilingual education in Ontario: A Canadian case study, Clevedon, UK: Multilingual Matters.

Swain, M., \& Lapkin, S. (2002) Talking it through: two French immersion learners' response to reformulation, International Journal of Educational Research, 37: 285-304.

Turnbull, M., Lapkin, S., \& Hart, D. (2001) Grade 3 immersion students' performance in literacy and mathematics: Province-wide results from Ontario (1989-99), The Canadian Modern Language Review, 58: 9-26. Wood, D., Bruner, J., \& Ross, G. (1976) The role of tutoring in problem solving. Journal of Child Psychology and Psychiatry: 17, 89-100. 